\title{
Seasonal abundance of small cladocerans in Lake Mangakaware, Waikato, New Zealand
}

\author{
TRACEY L. GREENWOOD* \\ JOHN D. GREEN \\ BRENDAN J. HICKS ${ }^{\dagger}$ \\ M. ANN CHAPMAN
}

Department of Biological Sciences

The University of Waikato

Private Bag 3105

Hamilton, New Zealand

*Present address: Biozone International Limited, P. O. Box 13 034, Hamilton, New Zealand.

\begin{abstract}
The seasonal changes in the dynamics and life histories of the Cladocera in Lake Mangakaware, North Island, New Zealand, were studied over 19 months by sampling at weekly or 2-weekly intervals. Lake Mangakaware is a 13.3 ha polymictic lake with high nutrient status, low Secchi disc transparencies, and an unstable thermal regime. The four planktonic cladoceran species (Bosmina longirostris, $B$. meridionalis, Ceriodaphnia pulchella, and $C$. dubia) exhibited disjunct population maxima. Only $B$. longirostris was perennially present. All species exhibited low fecundities and low lipid content, indicating that food resources were limited and that competitive interactions and resistance to starvation were probably important in determining species success. Increases in body size in cooler seasons were unrelated to clutch size, giving further support for the view that available food was limited. These results are consistent with previous experimental findings that subtle differences in life history can determine seasonal success and the outcome of competition between similar species.
\end{abstract}

Keywords Cladocera; Bosmina; Ceriodaphnia; seasonal abundance; life history; competition; New Zealand

${ }^{\dagger}$ Corresponding author. M98082

Received 2 December 1998; accepted 23 March 1999

\section{INTRODUCTION}

Cladocera are a prominent element of most lake zooplankton communities. In any one lake a variety of species usually coexist, ranging from large Daphnia to the smaller Ceriodaphnia and Bosmina species. The mechanisms allowing the co-occurrence of such a variety of species with apparently similar niche requirements have received considerable attention, and a number of explanations have been put forward. Perhaps that which has received most attention has been the Size-Efficiency Hypothesis. This hypothesis suggests that the predominance of large zooplankton species (e.g., Daphnia spp.) in habitats lacking visual predators is a consequence of their competitive superiority over small species (Brooks \& Dodson 1965). Large species are more efficient in food collection and have lower metabolic demand per unit mass than small species. However, when visual predation is intense, the larger, more visible species are very vulnerable, and small species can predominate (Hall et al. 1976).

A model of seasonal succession based on empirical evidence from lakes, reservoirs, and ponds acknowledged the importance of life cycle adaptations (e.g., the production of ephippia and persistence under starvation), competition for food resources, selective predation, and physiological constraints in zooplankton abundance cycles (Sommer et al. 1986). Other authors developed an evolutionary perspective (Lynch 1980a,b; Perrin et al. 1990; Ebert 1991), and emphasised patterns of growth and reproduction, i.e., the suite of adaptations collectively termed life history tactics (e.g., Stearns 1976). Focus on life histories has enabled a more realistic view of the important factors governing the dynamics of natural populations. Theoretical "optimal life histories" are based on the assumption that individual success depends on the relative allocation of energy to reproduction and growth (Stearns 1976). Key life history characteristics are clutch size, offspring size, age distribution of the reproductive effort, interaction of reproductive effort with adult mortality, and the variation of these traits among progeny (Stearns 1976). 


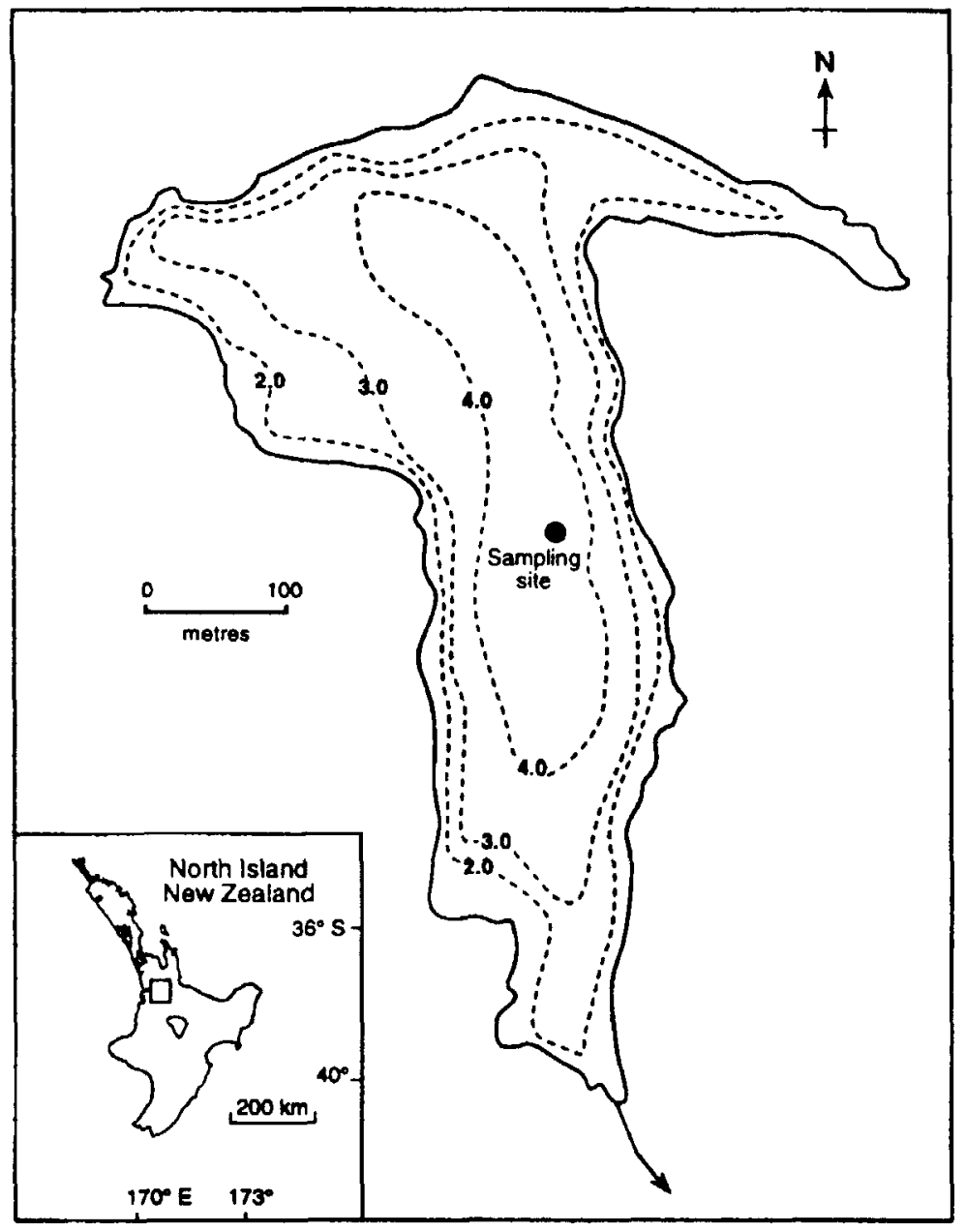

Fig. 1 Location of the sampling site on Lake Mangakaware, Waikato region, North Island, New Zealand. Outflow is indicated by the arrow.

Niche analyses that have shown spatial or temporal separation of peaks in abundance support the contention that competition is important in structuring zooplankton communities (e.g., Makarewicz \& Likens 1975). Separation of peaks of abundance is one way in which co-occurring species may avoid competition. However, such studies fail to show that the disjunct distributions are the result of competition, or even that competition is completely avoided.

By comparison to Northern Hemisphere systems, the cladoceran communities of New Zealand lakes have received little attention. In New Zealand, planktonic communities cunsist of few species (Chapman \& Green 1987), and often there may be only two cladocerans present. Until recently the most commonly occurring species were thought to be Ceriodaphnia dubia and Bosmina meridionalis, but $C$. pulchella and B. longirostris have now been reported from a range of North Island lakes (Greenwood et al. 1991), and in some lakes (e.g., small riverine lakes in the Waikato area) the four species co-occur. Daphnia is usually absent from New Zealand lakes, or occurs only sporadically, and the only species usually found is D. carinata (Chapman \& Green 1987). Copepods are also represented by only a few species.

There is some disagreement as to whether these distinctive characteristics of planktonic communities are associated with a relative absence of vertebrate and invertebrate predators (e.g., Chapman \& Green 1987; Burns 1992), or by contrast, continuous high predation pressure (e.g., Jeppesen et al. 1997). However, it seems likely that New Zealand zooplankton communities exist under conditions of low food availability that result from the mild, oceanic climate. Because there is year-round phytoplankton 
growth, zooplankton densities appear high compared to the available food resources (e.g., Chapman \& Green 1987), which may be dominated by large inedible algal species (Malthus \& Mitchell 1990). Consequently, competitive interactions between species may be of great importance in structuring New Zealand cladoceran communities.

In Lake Mangakaware, a small North Island lake, Daphnia is absent, planktivorous fish are very limited in abundance, and the major predator is likely to be the cyclopoid copepod Mesocyclops leuckarti (Greenwood 1993). The Bosmina species are more resistant to predation by Mesocyclops than the Ceriodaphnia species (Jamieson 1980). All four species cladocerans in Lake Mangakaware are similar in size when compared to the much larger Daphnia species, and subtle differences in life history strategies may permit their coexistence.

We examined the seasonal dynamics and life history strategies of the Cladocera in Lake Mangakware (Ceriodaphnia dubia, C. pulchella, Bosmina meridionalis, and $B$. longirostris). To compare the similarities and differences amongst the cladoceran life histories, we set two objectives: (1) to determine seasonal variations in abundance of the four planktonic cladoceran species in Lake Mangakaware; and (2) to relate the variations in the seasonal abundance to interspecific differences in fecundity and growth by assessing mean body size, clutch size, size at first reproduction, lipid storage, ovarian development, and the appearance of males and ephippial females.

\section{METHODS}

\section{Study site}

Lake Mangakaware $\left(37^{\circ} 55^{\prime} \mathrm{S}, 175^{\circ} 13^{\prime} \mathrm{E}\right)$ is a 13.3 ha, elongated, polymictic lake. The catchment is mainly in pasture with only narrow, broken margins of willows (Salix fragilis), flax (Phormium tenax), and raupo (Typha orientalis), and extensive marginal areas of submerged macrophytes (Elodea canadensis, Potamogeton ochreatus) and floating plants (Azolla rubra, Nymphaea spp.). Inflow to the lake occurs through numerous farm drains, and its outflow is at the southern end (Fig. 1). The lake has a mean depth of $2.93 \mathrm{~m}$ and maximum depth of $4.80 \mathrm{~m}$ (Fig. 1). Humic compounds from marginal areas of peat make the water moderately dark, and the Secchi disc transparency ranged from 0.5 to $2.0 \mathrm{~m}$ (Fig. 2). The lake has a high nutrient status (total Kjeldahl nitrogen (TKN) $0.480-1.400 \mathrm{~g} \mathrm{~m}^{-3}$;

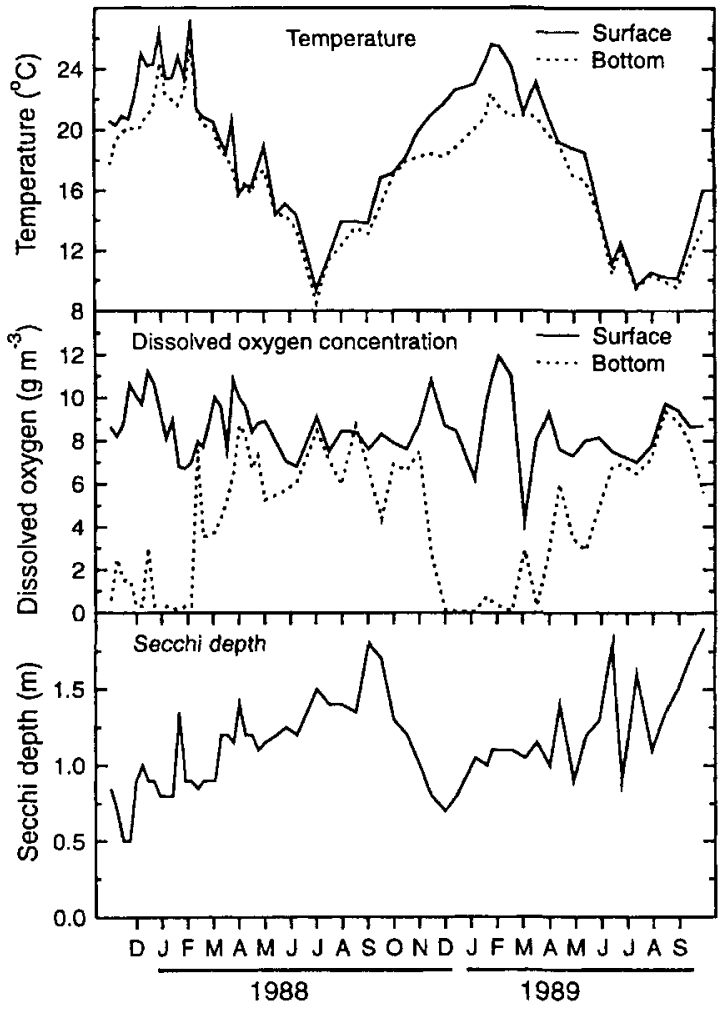

Fig. 2 Seasonal variation in temperature, dissolved oxygen concentration, and Secchi disc depth in Lake Mangakaware, New Zealand, between November 1987 and September 1989. total phosphorus (TP) $0.026-0.116 \mathrm{~g} \mathrm{~m}^{-3}$; Greenwood 1993), which is eutrophic according to the boundaries suggested by White (1983). Chlorophyll $a$ concentrations have ranged between 0.5 and 22.7 $\mathrm{mg} \mathrm{m}^{-3}$ (Greenwood 1987). During the study period the temperature ranged from 8 to $25^{\circ} \mathrm{C}$ (Fig. 2).

Few fish species occur in the lake. Small numbers of common bullies (Gobiomorphus cotidianus) have been found in littoral samples populations (Chapman \& Boubée 1977), but no larval fish were ever taken during this study, in either plankton samples, or in occasional drop-net samples (J. D. Green unpubl. data). Eels (predominantly Anguilla australis) are present and are periodically harvested by commercial fishers. Eels have their planktivorous stage at sea or down stream of Lake Mangakaware. 


\section{Field methodology}

Temperature and dissolved oxygen were measured from the surface to the bottom at $0.5 \mathrm{~m}$ intervals with a Yellow Springs Instruments meter (model 57) at the sampling site indicated in Fig. 1. Water transparency was measured with a standard $20 \mathrm{~cm}$ diameter Secchi disc. These measurements were made at 2weekly or monthly intervals, coinciding with zooplankton and phytoplankton collections.

To determine its abundance, the zooplankton was sampled over 19 months. Initially, weekly sampling was used to establish patterns of variation from early summer to early autumn (November 1987 and the end of April 1987). Thereafter, sampling was carried out at 2-weekly intervals to investigate abundance at other times of the year, and to confirm patterns of abundance in summer. Samples were collected using an electric diaphragm bilge pump at $1 \mathrm{~m}$ depth intervals from the surface to the bottom $(4 \mathrm{~m})$. The hose end was fitted with a four-way split piece, projecting horizontally from the base of the hose, to reduce problems of intake avoidance by the zooplankton. A sample of 20 litres was pumped from each depth through a short, conical net fitted with $47 \mathrm{~mm}$ plankton mesh held above the lake surface so that the bottom of the net was immersed in lake water. The zooplankton from each 20 -litre volume were washed into a sample container before the next depth sample was taken. All five depth samples were then combined and preserved with cold sucrose-formalin (final concentration about 4\%; Prepas 1978). Samples were refrigerated after collection to minimise the fading of visible lipid in the cladocerans.

Pumped samples were used in preference to net hauls for routine determination of zooplankton abundance because hauls of nets with mesh $<100 \mu \mathrm{m}$ clogged during the frequent periods with phytoplankton blooms. Coarser meshed nets did not clog, but also failed to representatively sample rotifers, small cladoceran instars, and copepod nauplii.

In addition to the pumped samples, the zooplankton were also sampled by two vertical net hauls, from the bottom to the surface, using a 0.92 $\mathrm{m}$ long Nansen-type net (mouth diameter $215 \mathrm{~mm}$ ) fitted with $47 \mu \mathrm{m}$ mesh, modified after the design of Currie \& Foxton (1967). When the abundance of any one species was low, these net hauls were used to supplement the pumped samples for analysis of cladoceran age structure and reproductive parameters.

Phytoplankton samples were taken with a 4-m long rubber phytoplankton tube with a $10 \mathrm{~mm}$ inside diameter. Each sample was run out into a container and well mixed, and then a subsample of $120 \mathrm{ml}$ was taken from the tube and fixed with Lugol's iodine to a pale straw colour before enumeration of the phytoplankton. This required about $2 \mathrm{ml}$ of Lugol's iodine for each $120 \mathrm{ml}$ subsample, depending on the density of algae and flocculant material.

\section{Laboratory methods}

For counting, the entire plankton sample was searched for species occurring in very low numbers (particularly Piona and Anisops species, which occurred in the plankton only sporadically), and then subsampled for the abundant taxa. The sample was diluted to a known volume, stirred using a figureof-eight motion, and a $5 \mathrm{ml}$ subsample withdrawn using a wide-mouthed automatic pipette, minimising vortices and thus avoiding unrepresentative subsamples (James 1991). Zooplankton numbers were then counted at a magnification of $31.5 \times$ using a stereomicroscope. The wide variation in the abundance of different species meant that different dilutions were required for the enumeration of a single sample. Generally, 30-150 individuals of each taxon were counted per subsample, and the subsampling was repeated until the results were reproducible. The mean count was then multiplied by the appropriate dilution factor to give the number litre $^{-1}$.

Taxonomic identification followed Chapman \& Lewis (1976) (for Copepoda and Arachnida); RuttnerKolisko (1974) and Koste (1978) for Rotifera; Smirnov \& Timms (1983) for the Chydoridae; and Greenwood et al. (1991) for Ceriodaphnia. Specimens of both Bosmina species were identified by V. Korinek (pers. comm.), but for $B$. longirostris s.l. these identifications are tentative. Calanoid and cyclopoid nauplii were enumerated together. Rotifers were identified to species wherever possible, but to genus only when the taxonomy was unclear.

Growth and fecundity of the cladocerans were assessed from size at first reproduction and clutch size. Body length was measured to the nearest $0.01 \mathrm{~mm}$ from the anterior margin of the head to the dorso-posterior edge of the carapace for Ceriodaphnia, and from the front of the head to the midpoint on the posterior margin of the carapace, excluding the mucro, for Bosmina. Measurements of both genera were made to within $0.01 \mathrm{~mm}$, except on occasions when carapace ballooning reduced the accuracy of measurement to c. $0.025 \mathrm{~mm}$.

At least 70-100 animals of each species were measured to determine the proportions of juveniles and adults, ovigerous and ephippial females, and 
Fig. 3 Lipid score (left) and ovary score (right) for Ceriodaphnia from Lake Mangakaware, New Zealand. The lipid-ovary index is given by the sum of scores for each parameter. Scores are illustrated for Ceriodaphnia pulchella, but are also applicable to $C$. dubia and Bosmina.
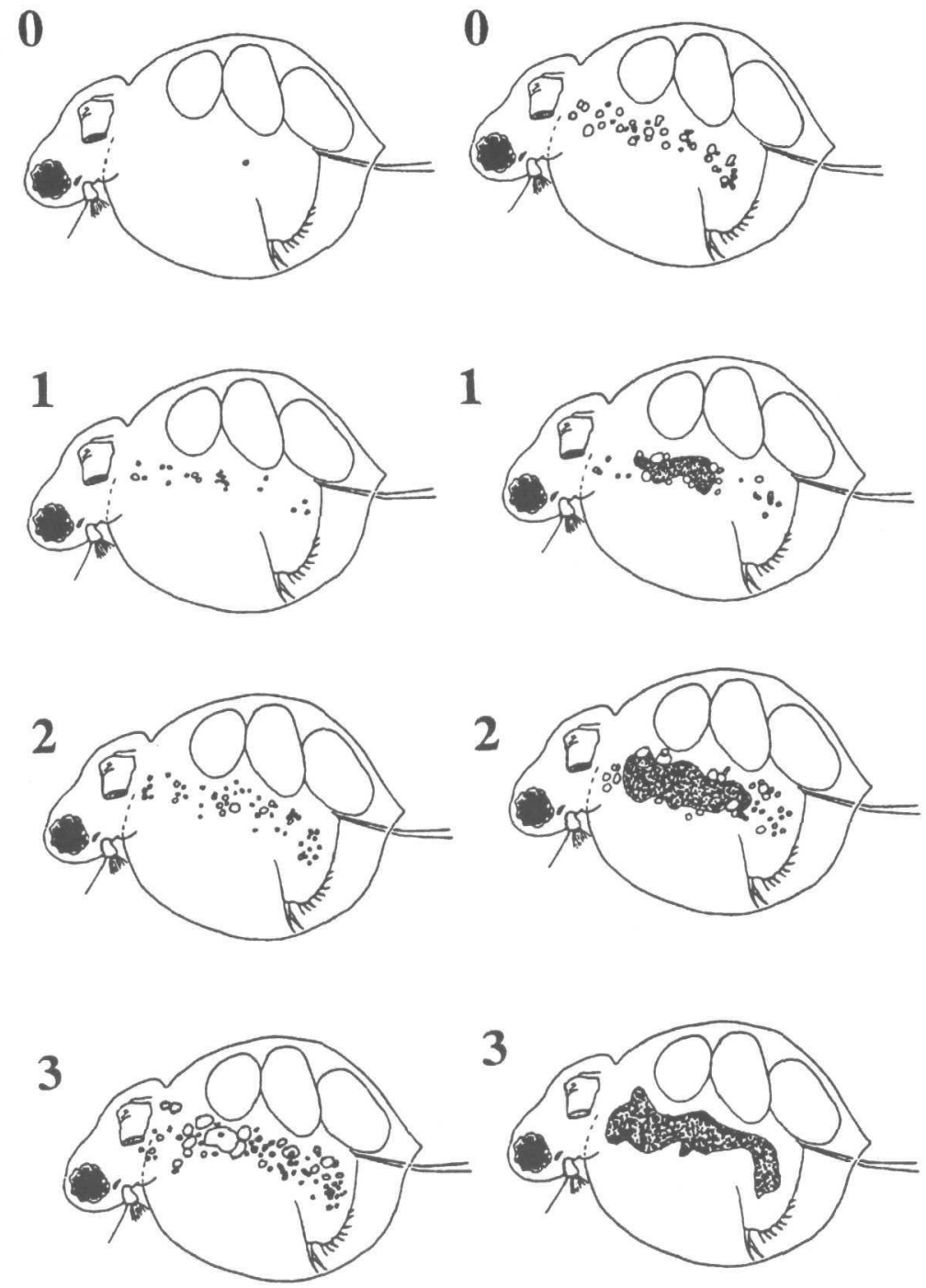

males. The adult females and juveniles of both Bosmina and Ceriodaphnia were separated on the basis of body shape, the adults having a pronounced brood pouch (with or without eggs) that is absent in the juveniles. Ephippial females of Bosmina were recognised by the ridged and thickened carapace, and those of Ceriodaphnia by the dark, sculpted appearance of the ephippium (Greenwood et al. 1991). Males of Bosmina were distinguished from females by a blunter, thicker rostrum and larger antennules. The males of Ceriodaphnia had a different body shape, larger antennules and long flagellum arising from the first trunk limb (Greenwood et al. 1991). Adult males of each species were recorded separately, but not assigned to an instar group. Within the juvenile section of the population, males could not be distinguished from females, and so could not be separately identified.

The number of eggs per female, recorded in at least 50 ovigerous females of each species, was used to give an estimate of population mean clutch size. The minimum size at first reproduction, a life history parameter that may vary in response to changing juvenile mortality (Lynch 1980a), was defined as the 
smallest size at which at least $10 \%$ of the adult population reproduced (Culver 1980).

At the same time as body sizes and reproductive data were recorded, animals from the field samples were scored for the amount of accumulated visible lipid and size of the ovaries if present (lipid-ovary index (LOI); Tessier \& Goulden 1982). The LOI was based on the size and number of lipid droplets within the body cavity, scored 0-3 (Fig. 3). Each animal was also scored $0-3$ for the size and opacity of the ovaries (Fig. 3). The LOI was the sum of these two. For juveniles where ovaries are immature, scoring was only possible for body-cavity lipid, and thus scores ranged from 0 to 3 for juveniles, and from 0 to 6 for adults. Tessier \& Goulden (1982) described how the visible lipid in cladocerans varies according to the stage of moult cycle. In early egg stages, energy reserves have only recently been allocated to reproduction, and even well-nourished animals appear low in lipid. For this reason, only animals with eggs in stages III-IV (Bosmina) or V-X (Ceriodaphnia) were used in calculating LOI values in adult ovigerous females. These egg stages correspond to Threlkeld's (1979) egg stages 2, 3, and 4, but a more detailed staging description was required here, to accommodate egg measurement, and to correspond to stages used in laboratory work (Greenwood 1993). For non-fecund females no egg-stage adjustment could be made.

Phytoplankton were counted using the sedimentation technique of Utermöhl (1958). The sampled was mixed gently but thoroughly, a known volume (4-25) $\mathrm{ml}$ was removed and settled for $24 \mathrm{~h}$, and the phytoplankton enumerated at magnifications of $200 \times, 400 \times$, and $800 \times$ with an inverted microscope. Counts were recorded as plankton units (Lewis 1978) because colonial species such as Actinastrum, Dictyosphaerium, and Sphaerocystis, and filamentous types (e.g., Aulacoseira) were not counted as individual cells, but as discrete entities. Phytoplankton were identified as inedible or of low food quality if the maximum cell or colony dimension was $>35 \mu \mathrm{m}$, or if they were cyanobacteria or green algae with gelatinous sheaths or hard coverings (Vanni 1987). Other taxa were considered to be palatable (i.e., edible and of high quality as food); these included naked green algae, flagellates, and small diatoms.

\section{Statistical analyses}

Pearson correlation analysis (Zar 1996) was used to investigate the relationship between temperature, phytoplankton abundance, and the abundance of predators and cladocerans. These analyses were carried out using SYSTAT 7.0 (Wilkinson 1997).

\section{RESULTS}

\section{Seasonal abundance}

The lake was generally stratified during the summer months, as shown by the temperature and dissolved oxygen at the surface and at the bottom, except for brief mixing episodes during windy periods (Fig. 2). Over the 19 months of the study, Cladocera accounted for $22 \%$ of the total zooplankton numbers, with the remainder divided similarly between copepods and rotifers (Table 1). Bosmina longirostris was the most abundant cladoceran $(13 \%$ of the total zooplankton), followed by Ceriodaphnia pulchella $(5 \%)$. Calamoecia lucasi was the

Table 1 Percentage contribution of the major $(>0.5 \%)$ zooplankton species and taxonomic groups to total zooplankton density in Lake Mangakaware, New Zealand, November 1987-September 1989.

\begin{tabular}{|c|c|}
\hline Taxonomic group & $\begin{array}{l}\text { Percentage of } \\
\text { total zooplankton }\end{array}$ \\
\hline Copepoda & 40.1 \\
\hline Rotifera & 38.2 \\
\hline Cladocera & 21.7 \\
\hline \multicolumn{2}{|l|}{ Cladocera } \\
\hline Bosmina longirostris & 12.8 \\
\hline Ceriodaphnia pulchella & 5.4 \\
\hline Bosmina meridionalis & 2.9 \\
\hline Ceriodaphnia dubia & 0.6 \\
\hline \multicolumn{2}{|l|}{ Copepoda } \\
\hline Total copepod nauplii & 24.6 \\
\hline Calamoecia lucasi* & 7.6 \\
\hline cf. Mesocyclops leuckarti* & 5.8 \\
\hline Boeckella delicata* & 2.2 \\
\hline \multicolumn{2}{|l|}{ Rotifera } \\
\hline Keratella cochlearis & 11.9 \\
\hline Pompholyx cf. sulcata & 6.5 \\
\hline Keratella sp. & 4.1 \\
\hline Conochilus sp. & 3.8 \\
\hline Asplanchna spp. & 3.4 \\
\hline Hexarthra mira & 2.0 \\
\hline Filinia cf. pejleri & 1.8 \\
\hline Trichocerca similis & 1.7 \\
\hline Synchaeta sp. & 1.3 \\
\hline Polyarthra remata & 1.0 \\
\hline Brachionus angularis & 0.4 \\
\hline
\end{tabular}

*Adults and copepodites. 
predominant copepod throughout the sampling period ( $8 \%$ of the total zooplankton), followed by Mesocyclops leuckarti (6\%) and Boeckella delicata $(2 \%)$. The rotifer population was dominated by Keratella cochlearis, which accounted for $12 \%$ of the total zooplankton; the rest of the rotifer community comprised mainly Pompholyx cf. sulcata (7\%), Keratella sp. (4\%), Conochilus sp. (4\%), and Asplanchna (3\%), with the remaining 10 species each comprising $<2 \%$ of the total zooplankton. Apart from a strong peak in the abundance of rotifers in early February 1989 when densities reached almost 5000 per litre ${ }^{-1}$ (mostly attributable to Keratella cochlearis), there were no particular patterns to the total rotifer abundance. Mesocyclops leuckarti was abundant throughout most of the sampling period, with peaks of abundance in summer to early winter and very low numbers during the winter months (Fig. 4). Phytoplankton that were assumed to be palatable (i.e., Scenedesmus, Actinastrum, Coelastrum, Kirchneriella, Vacuolaria, Cryptomonas, and Monoraphidium) were present for most of the time, but at much lower abundances than other less palatable phytoplankton, such as Aulacoseira and Tetrastrum.

Cladoceran species exhibited pronounced patterns of seasonal replacement, and widely variable densities were achieved by each species $\left(>1100\right.$ litre $^{-1}$ for Bosmina longirostris compared to 47 litre $^{-1}$ for $C$. dubia; Fig. 4). Each species had a period during which it was the dominant cladoceran. Bosmina longirostris was the most persistent, and was present throughout almost the entire sampling period. Numbers of $B$. longirostris were low from the time of its appearance at the beginning of March until it increased sharply in early summer 1989. Then followed a sharp decline and somewhat lower but variable numbers throughout the summer and early winter.

Peaks in abundance were not repeated seasonally. The period of peak abundance for Bosmina meridionalis was extremely short, with a sharp peak in abundance in December of 1987 , followed by a rapid decline and disappearance from the plankton by mid June 1988. It reappeared briefly in April 1989 in low numbers and on only two occasions. The decline in abundance of $B$. meridionalis was followed in February by a rapid increase in the abundance of Ceriodaphnia pulchella, which rose to a peak in March 1988, then declined in a fluctuating manner, remaining rather low and stable through winter and spring. C. pulchella had disappeared from the plankton by December 1988, and did not reappear
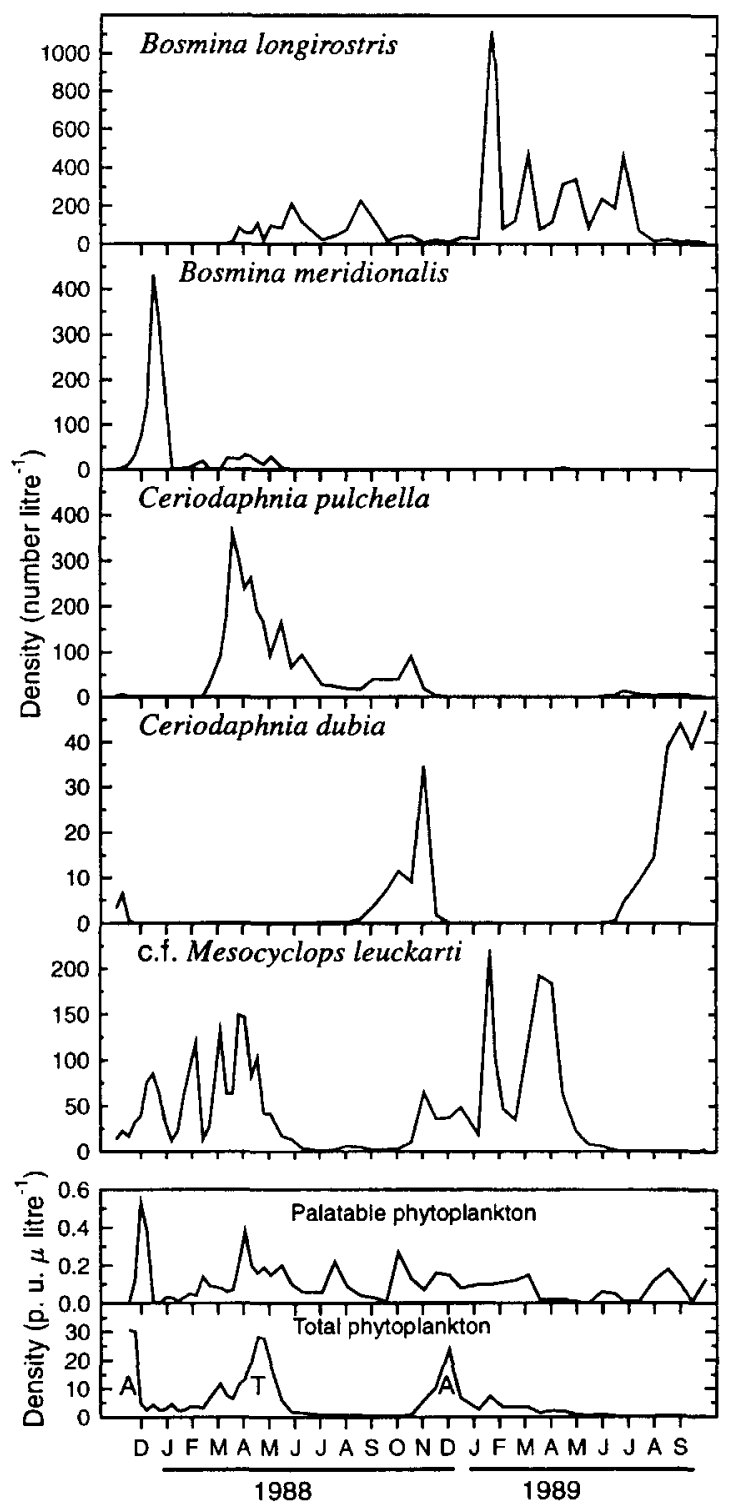

Fig. 4 Seasonal variation in the numbers of Bosmina, Ceriodaphnia, cf. Mesocyclops leuckarti, and phytoplankton abundance in Lake Mangakaware, New Zealand, from November 1987 to September 1989. (A, peak of abundances of Aulacoseira; T, peak of abundance of Tetrastrum; p. u., plankton units.)

until the following winter and then only in low numbers.

Ceriodaphnia dubia increased in abundance in the winter and spring of 1988 , following the decline in abundance of $C$. pulchella. Peak abundance of C. dubia was reached at the beginning of November, 
just before the disappearance of C. pulchella. Following its peak in abundance, $C$. dubia disappeared for almost 5 months, and was not recorded again until May 1989 when it increased dramatically through winter to an early spring peak at the end of the sampling period, during which time it was the predominant cladoceran. At the time of $C$. dubia's dramatic increase in July 1989, the abundance of $B$. longirostris was already low, and remained so until the end of sampling. Notably, C. dubia was the only species to show population increases coinciding with periods of low Mesocyclops leuckarti abundance.

The seasonal replacement of Cladocera was thus quite clearly defined, with $B$. meridionalis (December 1987) being followed by a peak in C. pulchella density (March-April 1988), a brief increase in $C$. dubia (October-November 1988), and a cycle in 1989 where the Cladocera were dominated first by $B$. longirostris and then by $C$. dubia. Although $B$. longirostris maintained a reasonably high abundance throughout most of 1988 , there was a clear spring decline in 1988 coincident with the peak in C. dubia density. Except for the repeated peaks in abundance of C. dubia no clear annual cycles were evident. This suggests that either food resources also lack annual cycles, or that some other factor such as predation or competitive interactions drive the sequential appearances of cladocerans. As the main predator in the lake (M. leuckarti) appears to influence only $C$. dubia, competitive interactions are a possible cause of the peaks in abundance.

\section{Reproductive parameters}

\section{Bosmina longirostris}

The proportion of ovigerous females at any one time was generally inversely related to the total population, falling when total numbers increased and increasing when they were low (Fig. 5). Fluctuations in mean clutch size were similarly variable. For much of the sampling period, clutch sizes (calculated only from egg-bearing females) remained at a minimum of one, with fluctuations around a clutch size of 1.5 eggs per female being more common during the period from late winter 1988 to early summer 1989.

The seasonal pattern in size of first reproduction was generally one of larger body sizes during autumn, winter, and spring, with a noticeable decrease over the summer period (Fig. 5). Size at first reproduction was negatively correlated with water temperature $(r=-0.85, N=43, P<0.001)$. Ephippial females were recorded on one date during the

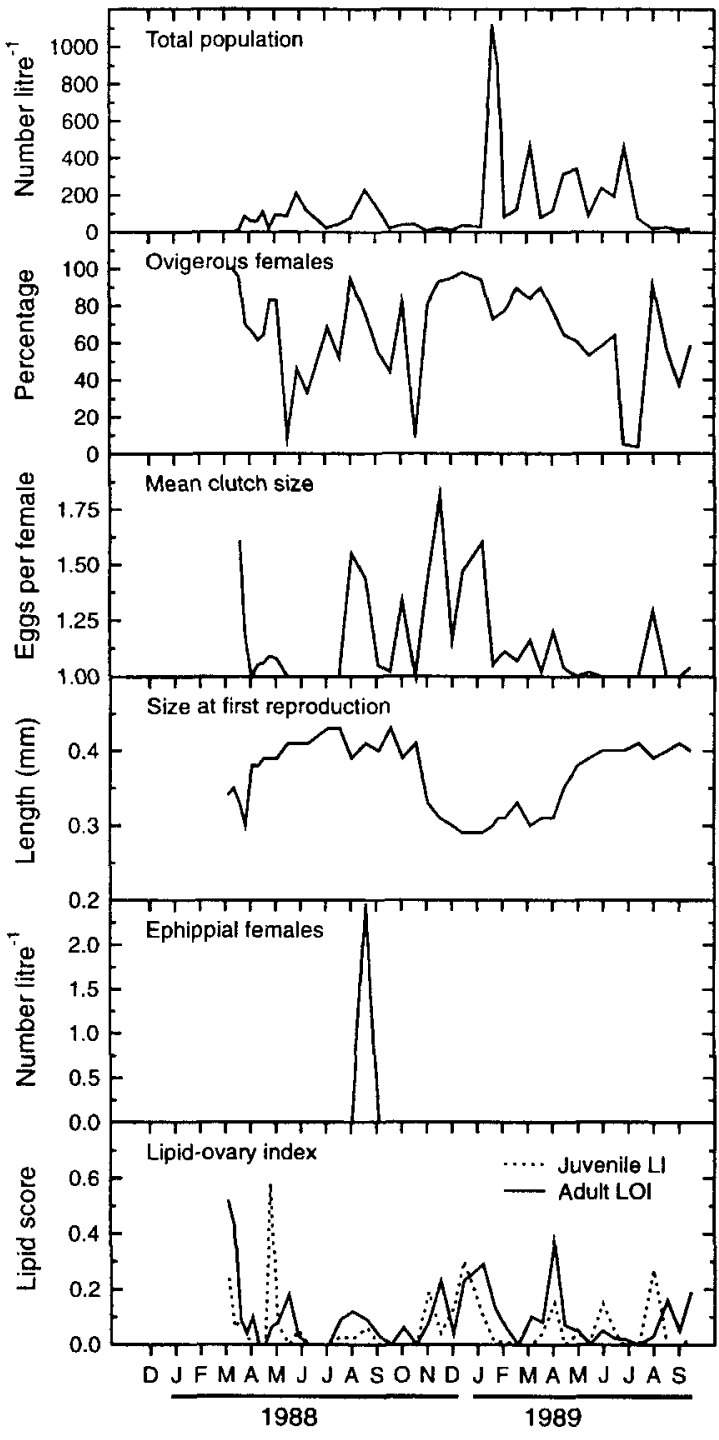

Fig. 5 Seasonal variation in the total population and reproductive parameters of Bosmina longirostris in Lake Mangakaware, New Zealand, from November 1987 to September 1989. (LI, lipid index; LOI, lipid-ovary index.)

sampling period, in August 1988, when they accounted for $3 \%$ of the adult females. This peak occurred 4 months before the peak in population density.

\section{Bosmina meridionalis}

There were similar general trends in the proportions and numbers of ovigerous females and the mean clutch size in B. meridionalis (Fig. 6). Large increases in the number of egg-bearing females 


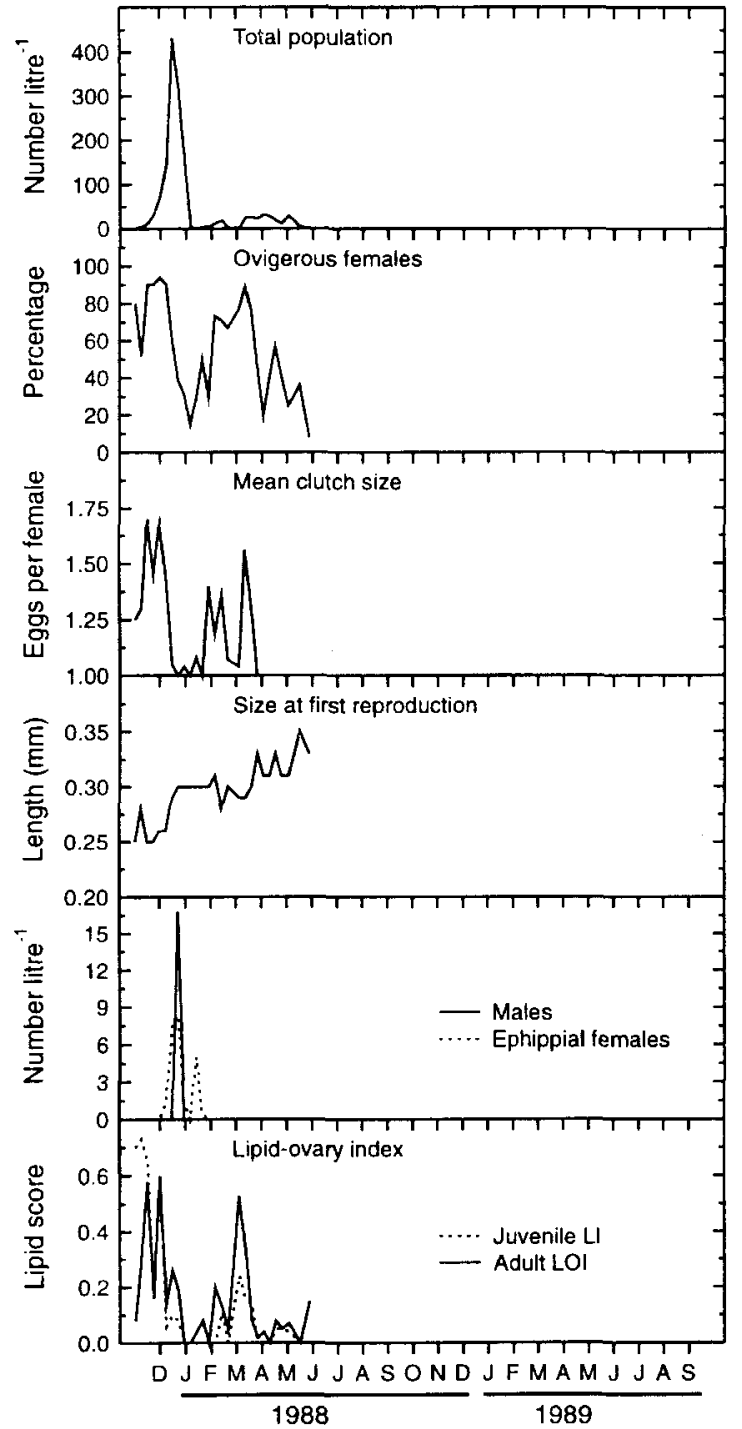

Fig. 6 Seasonal variation in the total population and reproductive parameters of Bosmina meridionalis in Lake Mangakaware, New Zealand, from November 1987 to September 1989. (LI, lipid index; LOI, lipid-ovary index.)

during November and December 1987 coincided with a maximum in mean clutch size. Increases in these variables in late summer and autumn in 1988 were less pronounced but the coincidence of the patterns remained, with higher mean clutches being associated with increases in the proportion of females bearing eggs. As for $B$. longirostris, body size at first reproduction was negatively correlated with water temperature $(r=-0.41, N=27, P=0.034)$,

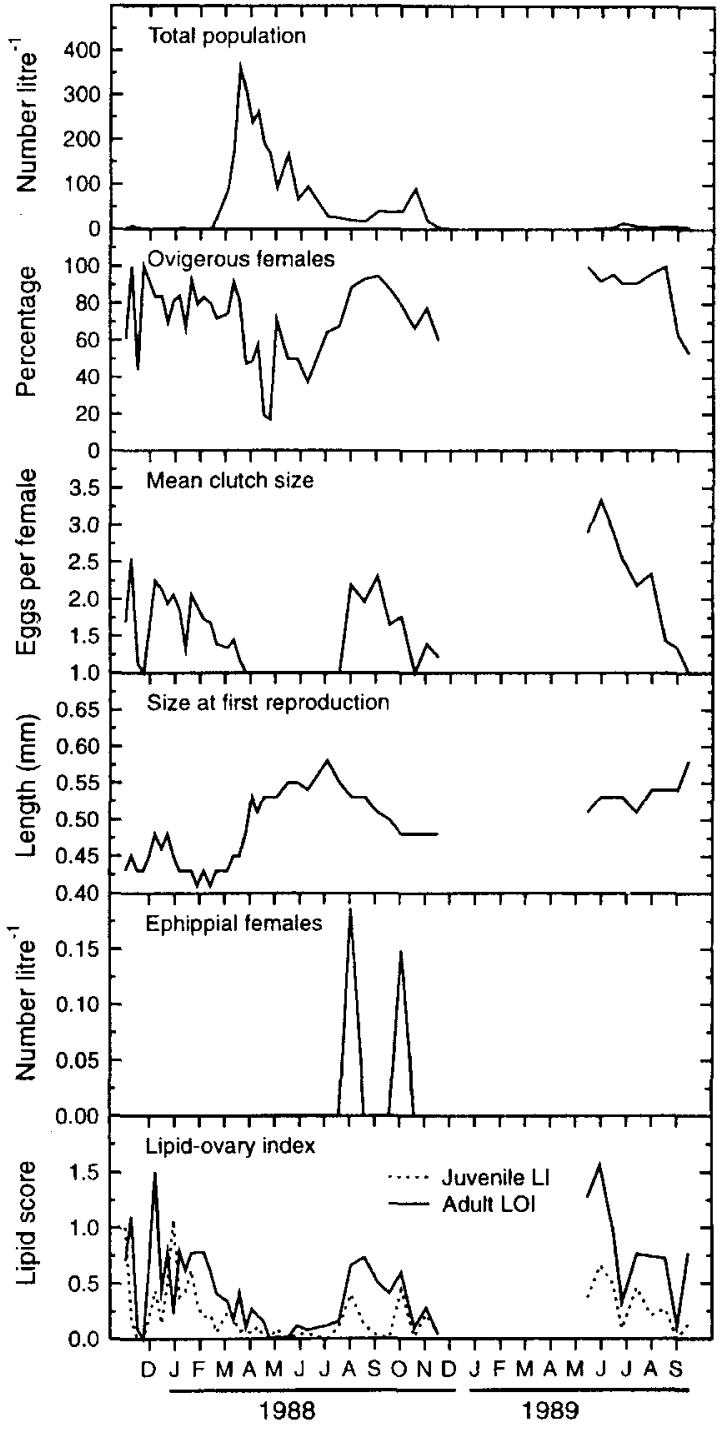

Fig. 7 Seasonal variation in the total population and reproductive parameters of Ceriodaphnia pulchella in Lake Mangakaware, New Zealand, from November 1987 to September 1989. (LI, lipid index; LOI, lipid-ovary index.)

and increased during cooler periods from a mean of $0.265 \mathrm{~mm}$ in December 1987 to a mean of $0.323 \mathrm{~mm}$ in May 1988. Ephippial females were recorded for a brief period at the time of peak abundance.

\section{Ceriodaphnia pulchella}

Peak population abundance was associated with a sharp decline in the proportion of the adult population bearing eggs (Fig. 7). When population 
numbers were lower, as they were in summer 1987 88 and in winter and spring periods, the proportion of egg bearers was high, particularly during MayAugust 1989. Similarly, mean clutch sizes were lowest just after the autumnal density peak and declines in mean clutch size were always coincident with increases in total population density, as in mid October 1988 and late June 1989. As with Bosmina, size at first reproduction was negatively correlated with water temperature $(r=-0.83, N=47, P<0.001)$. Larger body sizes were clearly associated with low clutch sizes, and animals were at their most fecund when body sizes were small.

Ephippial females were recorded on two occasions, in early August, and again in early October. Although obvious by their morphology, even at their peak abundance in August 1989 ephippial females accounted for only $1.8 \%$ of the adult females present.

\section{Ceriodaphnia dubia}

Analysis of reproductive parameters of C. dubia was often hampered by low numbers of this species. $C$. dubia was unusual amongst the planktonic Cladocera in Lake Mangakaware in that a generally high proportion ( $>90 \%$ ) of the females were ovigerous (Fig. 8 ). Only during one period (October-November 1988) did the proportion of ovigerous females fall significantly. This decline just preceded the rise in total population numbers and, as for $C$. pulchella, was associated with a sharp decline in mean clutch size (Fig. 8). The proportion of the females that were ovigerous was inversely related to the density $(r=$ $-0.47, N=47, P=0.001$ ).

Trends in body size at first reproduction (Fig. 8) were more difficult to discern than in C. pulchella or $B$. longirostris, particularly as C. dubia occurred over a restricted seasonal range. However, as for the other species, size at first reproduction was negatively correlated with water temperature $(r=-0.57, N=20, P=$ 0.009). Low densities in July 1988 and June 1989 may account for the apparently large mean body sizes recorded for primiparous females at these times. Discounting these periods, body size changes over the period during which $C$. dubia was abundant were minimal, although, as with Bosmina and C. pulchella, there was a tendency for animals to be larger during cooler months. During both periods of peak abundance (October-November 1988 and August--September 1989), males and ephippial females were recorded, the former reaching a maximum $12 \%$ of the population on 19 October 1988 and a maximum density of 2.1 litre $^{-1}$ on 2 November 1988.

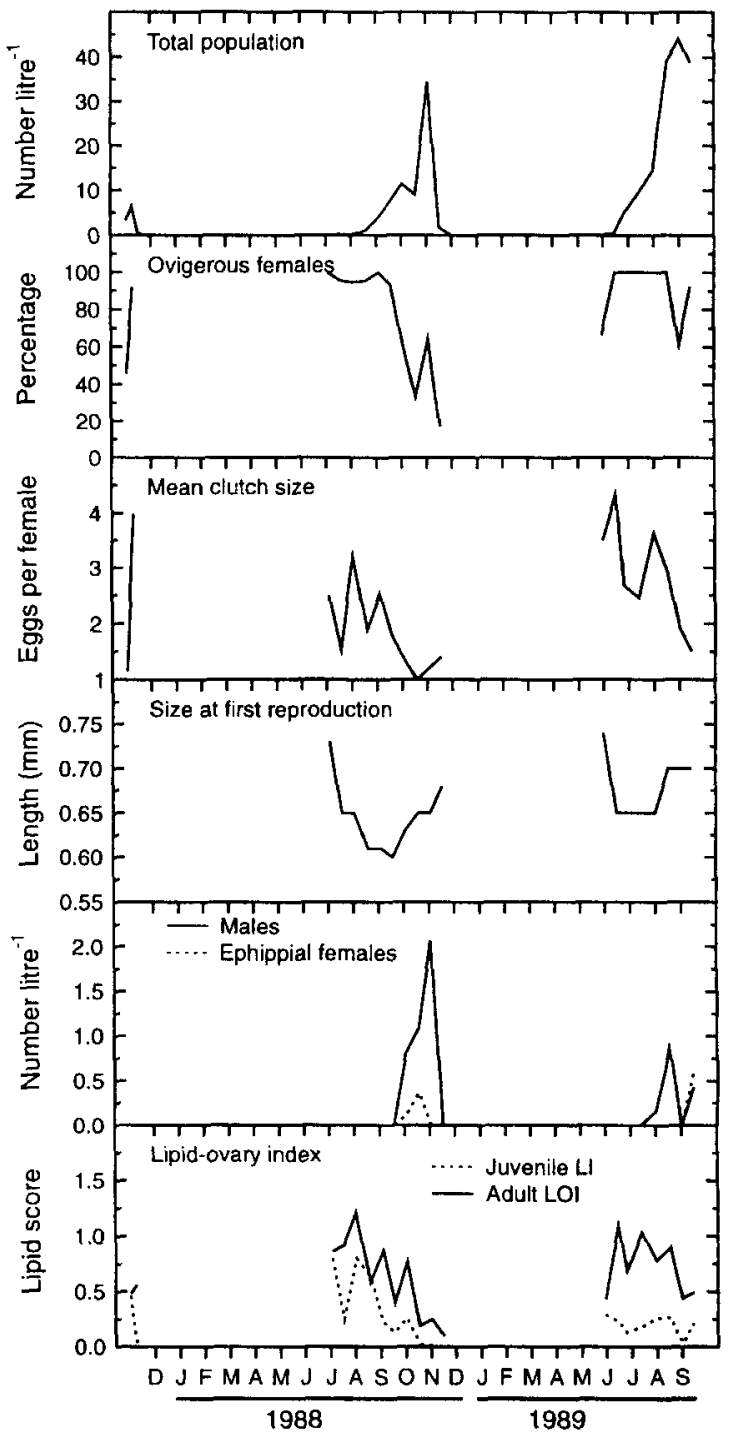

Fig. 8 Seasonal variation in the total population and reproductive parameters of Ceriodaphnia dubia in Lake Mangakaware, New Zealand, from November 1987 to September 1989. (LI, lipid index; LOI, lipid-ovary index.)

\section{Lipid-ovary index}

\section{Bosmina longirostris}

With the exception of the period from mid April to mid May 1988, B. longirostris exhibited similar patterns of lipid storage in both juveniles and adults (Fig. 5). Mean LOI scores were consistently low (mostly $<0.3$ ) and generally fluctuated around levels of c. $0.1-0.15$. The only noticeable increase in visible lipid was recorded in autumn (April-May) 
1988, when the mean LOI score for juveniles peaked at just below 0.6. Smaller peaks occurred the following summer and during the autumn of 1989 , but apart from this being a time when $B$. longirostris was generally abundant, these were not clearly associated with any peaks in density. There was, however, a general tendency for LOI scores to increase at the same time as the mean clutch size and the proportion of egg-bearing females. This relationship was particularly close for the second half of 1988 .

\section{Bosmina meridionalis}

As for $B$. longirostris, the mean LOI scores for $B$. meridionalis were consistently low $(<0.7)$ (Fig. 6). Peaks in lipid score were recorded for both juveniles and adults during the period of maximum population density in November-December 1987. However, later increases in lipid storage, particularly for adults (in March 1988), were not associated with pronounced changes in population density, although they were coincident with increases in the proportion of ovigerous females and the mean clutch size. Periods with high LOI for B. meridionalis (Fig. 6) also appeared to coincide with peaks in phytoplankton abundance in December and March (Fig. 4).

\section{Ceriodaphnia pulchella}

LOI scores in C. pulchella were generally higher and more variable than those in Bosmina, fluctuating from almost 0 to c. 1.5 (Fig. 7). Minimum lipid scores for both juveniles and adults occurred at the times of highest population density i.e., through autumn and winter 1988. Scores were higher when population density was lower and more stable. As for Bosmina, higher lipid scores were associated with higher mean clutch sizes and increases in the proportion of egg bearing females.

\section{Ceriodaphnia dubia}

As for $C$. pulchella, LOI scores were at times higher and more variable for $C$. dubia than for either species of Bosmina, fluctuating between 0 and 1.25 (Fig. 8). Similarly, adult scores were consistently higher than those recorded for juveniles. Scores for C. dubia were highest when the population was low (but increasing) in late winter 1988, and began declining as the population density increased during spring of that year. Minimum LOI scores were coincident with maximal population abundance in early November. A similar pattern held during 1989, although the trend was less apparent in that year. As was the case for the other cladoceran species, declining LOI

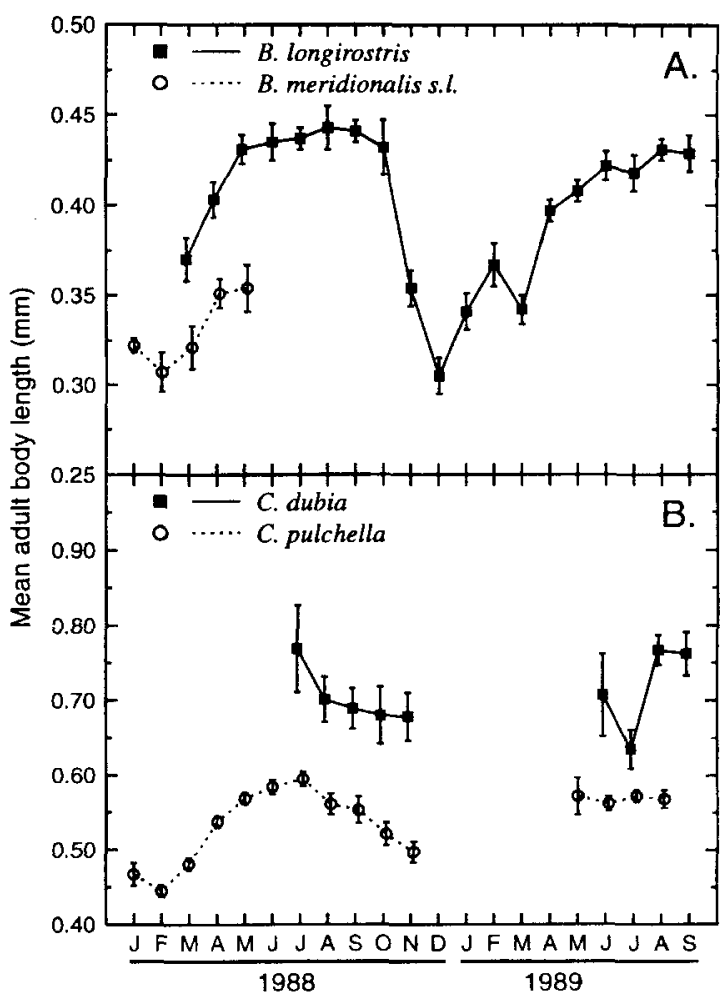

Fig. 9 Variation in mean adult body size in: A, Bosmina; and B, Ceriodaphnia in Lake Mangakaware, New Zealand, from November 1987 to September 1989. Vertical bars are $95 \%$ confidence intervals.

scores were closely associated with declining clutch sizes and a fall in the proportion of females bearing eggs.

\section{Mean adult body size}

The monthly trends in the mean adult body size in Ceriodaphnia and Bosmina (Fig. 9) were similar to those recorded for size at first reproduction. All four species showed a tendency toward larger body size during winter periods, with a general decline in size in the spring and/or summer. This trend was most pronounced in $B$. longirostris, for which a complete annual cycle was recorded. Incomplete seasonal data for B. meridionalis, C. pulchella, and C. dubia made it difficult to establish whether or not small body sizes were typical of these species at very high (e.g., summer) temperatures, although the trends in the data indicate this. Over the entire study period, mean body size of $C$. pulchella was inversely related to water temperature $(r=-0.68, N=19, P<0.001)$. 


\section{DISCUSSION}

\section{Seasonal succession}

Lake Mangakaware is a dynamic environment, with marked seasonal changes in temperature and stratification, and with clear peaks in abundance of phytoplankton and zooplankton. The causes of the fluctuations in cladoceran abundance were complex. Bosmina's feeding mode is well suited to the selection of palatable algal species from the available food resource base (De Mott 1982), and B. longirostris was the most successful cladoceran species in Lake Mangakaware. It is able to feed selectively on palatable algal species even when the density of unpalatable or nutritionally poor taxa is high (Geller \& Muller 1981). The life history pattern of $B$. longirostris also predisposed it to success in this lake; it is a small species that produces relatively large eggs, and therefore large neonates, which develop quickly (Greenwood 1993). Like B. meridionalis, B. longirostris is relatively resistant to predation from Mesocyclops (Jamieson 1980), which is probably the only invertebrate predator of importance in Lake Mangaware throughout most of the year (Greenwood 1993). Although fecundities of both Bosmina species were lower than for the Ceriodaphnia species, juveniles of $B$. longirostris were evidently not very susceptible to the detrimental effects of food depletion. Although Threkeld's (1976) models predicted that larger bodied cladocerans should be able to persist at lower food levels than smaller species, subsequent studies (e.g., Lynch 1978; Lynch 1980b; Romanovsky \& Feniova 1985) have shown that the competitive advantage usually lies with small-bodied forms. Despite the higher feeding efficiencies of the larger species under conditions of high food availability, production rates were depressed more severely under conditions of low food availability than those of small species (Tessier \& Goulden 1987). In Lake Mangakaware, is possible that bacteria, the abundance of which was not measured, were an important food source (e.g., Lair 1991).

Both species of Bosmina, but particularly $B$. meridionalis, exhibited a "boom and bust" pattern of population change, with rapid growth followed by sharp declines in fecundity and density. A similar pattern was shown by the palatable phytoplankton in Lake Mangakaware, suggesting that though we may not have identified the individual food sources used by each species, clear peaks of food abundance occurred. Also, B. longirostris maintained a reproductively active population throughout the year, even when a high proportion of adults ceased to breed. The persistence of non-ovigerous females in the population, through periods unfavourable for breeding, enabled rapid reproduction once environmental conditions improved. This avoided the lag associated with the hatching of resting eggs and development of juveniles to reproductive age.

Both the Ceriodaphnia species were less persistent in the plankton than B. longirostris. C. pulchella was predominantly an autumnal species, occurring when the water was still warm, but temperatures were declining. The ability of $C$. pulchella to complete its growth to maturity and to reproduce under severe food deprivation makes it the more success ful Ceriodaphnia species in Lake Mangakaware (Greenwood 1993). In contrast to C. pulchella, the seasonality of $C$. dubia appears to involve a strong positive response to low temperatures. $C$. dubia was most abundant during the cooler spring temperatures, which is consistent with its ability to grow rapidly at low temperatures (Greenwood 1993). At $10^{\circ} \mathrm{C}$, egg development in C. dubia is 2 days faster than in C. pulchella and B. meridionalis (Greenwood 1993). Also, C. dubia appears to maximise this advantage by developing quickly to reproductive age when temperatures are low. C. dubia produces relatively smaller neonates than $C$. pulchella and hence may be more adversely affected by time spent before maturity at low food levels. C. dubia also suffered the highest mean death rates, suggesting that this species might also be highly vulnerable to predation or juvenile starvation (Greenwood 1993). Both factors may be important for $C$. dubia in Lake Mangakaware. It was the only cladoceran species to show an inverse abundance relationship with Mesocyclops leuckarti, the only potential invertebrate predator in the lake. There is no question that Mesocyclops leuckarti is a predator of small cladocerans, particularly Ceriodaphnia (Jamieson 1980), although C. pulchella, being the smaller of the two Ceriodaphnia species might reasonably be expected to be the most vulnerable to predation by Mesocyclops leuckarti. In the shallow, polymictic Lake Tjeukemeer in the Netherlands the invertebrate predator Leptodora kindtii appeared to control birth rates of C. pulchella (Boersma \& Vijveberg 1996), but invertebrate predation did not appear to be important in governing the abundance of this species in Lake Mangakaware.

Food limitation affects different cladoceran species in different ways. In particular, juvenile starvation has been recognised as a competitive bottleneck in the dynamics of food limited populations (Romanovsky 1984a,b; Romanovsky \& Feniova 1985). Although Lake Mangakaware is very 
productive (Greenwood 1993), this does not necessarily imply high food availability or quality, particularly as zooplankton densities were high, and palatable phytoplankton species may have been subjected to heavy grazing pressure and swamping by larger inedible types. Nutritional quality was not assessed in this study, but using the criteria of Lair (1991) some phytoplankton can be assumed to be palatable and of high food value to cladocerans (e.g., Scenedesmus, Actinastrum, Coelastrum, Kirchneriella, Vacuolaria, Cryptomonas, and Monoraphidium). These palatable genera were found at low densities relative to other less palatable phytoplankton, such as Aulacoseira and Tetrastrum.

Although disjunct patterns in the timing of peak abundances do not necessarily imply competitive displacement, the generally low fecundities and lipid scores of the Cladocera in Lake Mangakaware suggest that food depletion was important in the seasonality of species replacement in this lake. In contrast, in Lake Tjeukemeer changes in food quality or quantity did not appear to affect birth rates of C. pulchella (Boersma \& Vijveberg 1996).

A number of studies have examined seasonal succession and coexistence of cladoceran species in natural systems (e.g., Lynch 1978; De Mott 1983; Tessier 1986). Many of these studies have dealt with the way in which species partition food resources or respond to fluctuating food levels. Large-bodied daphnids have been speculated to feed efficiently on a wide range of particle sizes, but Bosmina's coexistence with Daphnia has been related to its efficient feeding on highly edible algal species, especially when these occurred in low densities (De Mott \& Kerfoot 1982). In New Zealand, food limitation is probably a general feature of zooplankton populations (e.g., Lynch 1980b; Chapman \& Green 1987). Prevalence of food limitation may explain the infrequent occurrence of Daphnia in New Zealand, and the dominance of small cladoceran species, as occurred in this study. However, a recent analysis of New Zealand data has suggested that the role of predation by zooplanktivorous fish in structuring zooplankton communities may have been underestimated, and may be the cause the widespread absence of Daphnia (Jeppesen et al. 1997). We do not believe that fish are significant zooplanktivores in Lake Mangakaware. In Lake Pounui, the smallest eels ( $130 \mathrm{~mm}$ long) were too large to be planktivorous. In this lake, eels were opportunistic feeders, eating primarily benthic invertebrates (Jellyman 1989). The bully populations in Lake Mangakaware were too restricted to have much effect on the zooplankton abundance, and no fish were ever caught in plankton samples.

\section{Gamogenesis}

Gamogenetic individuals was common in the cladoceran community, and was recorded for $C$. pulchella and Bosmina in 1985 also (Greenwood 1987). Sexual reproduction in Cladocera is a strategy for persistence in a fluctuating, often unfavourable, environment. Records of sexual reproduction in New Zealand cladoceran populations, however, are sparse. Ephippial Ceriodaphnia have been recorded in Lake Ngapouri (Chapman et al. 1985), the Auxiliary Nihotupu Reservoir (Green 1968), and Lake Grasmere (Staples 1984), and Donovan (1970) recorded ephippial Bosmina in Lake Ototoa, although males were not found. In these studies, ephippial production was associated with high population densities, rather than with a requirement for an overwintering stage.

For B. meridionalis and C. dubia both males and ephippial females occurred at the time of peak population density. However, this was not the case for $B$. longirostris and $C$. pulchella, where ephippial females were recorded respectively 4 months before, and 4 months after, peak densities. Neither of these two species produced males from 1987 to 1989 , in contrast to C. pulchella in 1985 (Greenwood 1987) where gamogenetic animals occurred at the highest population density, and both males and ephippial females were recorded. This suggests that the cues for the production of males and ephippia are different for B. longirostris and C. pulchella than for $C$. dubia and $B$. meridionalis.

Like the cessation of breeding, the switch to sexual reproduction is a bet-hedging strategy for persistence in a fluctuating environment. However, whereas the production of ephippia in $B$. meridionalis, C. pulchella, and C. dubia was associated with their disappearance from the plankton, this was not the case for $B$. longirostris. Clearly, in this species, sexual induction is not necessarily associated with environmental conditions unfavourable enough to result in population extinction. Rather, for $B$. longirostris, ephippial production was another method for ensuring the persistence of this more perennial species.

\section{Variation of body size and feeding success}

In both Ceriodaphnia and Bosmina seasonal increases in body size were generally associated with decreasing temperature. The inverse relationship 
between body size and temperature in Cladocera is well recognised (e.g., Burgis 1967; Kerfoot 1974; Culver 1980) and much attention has been given to seasonal variations in the size at first reproduction in particular. Vijverberg (1980) recorded a general trend for cladocerans at high temperature to mature at a small size, and Green (1956) noted that both starvation and increasing temperature reduced body size in Daphnia. Duncan (1989) noted that food limitation reduced body size and increased the age of maturation. These effects were attributed to the high cumulative costs of respiration through a protracted juvenile period. Similarly, Gophen (1976) found that increasing temperature affected body size in $C$. reticulata through increased respiration rates that caused an energy deficit and a decline in both body size and egg production. Temperature increases thus preceded a progressive decline in the population. Conversely, for C. dubia taken from forested Alabama floodplain swamps and raised at a range of temperatures in the laboratory, final body size decreased with decreasing temperature (Anderson \& Benke 1994). With no food limitation, temperature had no effect on size at first reproduction. The range of mean length at first reproduction found by Anderson \& Benke $(0.62-0.68 \mathrm{~mm})$ was similar to our results $(0.60-0.74 \mathrm{~mm}$; Fig. 8). Food limitation appears to be more important than temperature in determining body size in cladocerans. It is likely that there is a dynamic relationship between food limitation, temperature, and size at first reproduction whereby respiratory costs at high temperature cannot be offset when food is limited.

Of the four species, absolute changes in body size were greater for $C$. dubia than for C. pulchella or Bosmina, which are smaller species and thus less flexible in the degree to which body size varies when environmental conditions change. In agreement with this, maximum mean clutch sizes were greatest for the largest species $(1.7,2.6,3.3$, and 4.3 for $B$. meridionalis, $B$. longirostris, $C$. pulchella, and $C$. dubia respectively). Since body size places limits on the number of eggs that can be carried (Green 1956), both C. pulchella and Bosmina are potentially more limited in their fecundity anyway, simply because they are smaller. Notably though, the fecundities of all species were reduced below those recorded in laboratory cultures (Donovan 1970; Staples 1984; Greenwood 1987, 1993; Urabe 1991) giving further support for the conclusion that food depletion has limiting effects on clutch size in Lake Mangakaware.

C. pulchella could be regarded as intermediate in its life history between the boom and bust, small-bodied $B$. longirostris, and the larger, potentially more fecund C. dubia. C. pulchella has proved an extremely difficult species to rear in the laboratory (pers. obs.; C. Hickey pers. comm.) and its exact food requirements appear to be very specific.

$C$. pulchella's appearance after $B$. meridionalis numbers had declined may indicate different resource bases in these two species. It does, however, appear to be fairly resistant to starvation and, like $B$. longirostris, high proportions of the adults were nonfecund at times. This was also the case in Lake Rotoroa (Hamilton Lake) where the occurrence of large numbers of starving, non-fecund animals was even greater (T. L. Greenwood unpubl. data).

\section{Synthesis}

The long-term coexistence of the cladocerans in Lake Mangakaware, and their different patterns of seasonal abundance, are probably attributable to relatively small differences in their abilities to take advantage of pulses in the availability of suitable food. This includes the advantage of rapid development time for some species and the ability to persist when food pulses are infrequent or unpredictable. Although peak abundances of cladocerans were disjunct, the sequence of species replacement was somewhat predictable. Rapid fluctuations in the food resource base in Lake Mangakaware may allow competitive advantages to alter quite quickly away from one species, in favour of another. The adaptive features of $B$. longirostris are well suited to this type of environment and both temporally, and in terms of abundance, it could be regarded as the most successful cladoceran in this lake. Moreover, it is widespread in New Zealand lakes generally (Greenwood et al. 199I).

The factors governing the relative successes of the two Ceriodaphnia species seasonally are less easily pinpointed. Both species have potentially higher fecundities than Bosmina, but this does not seem to advantage them particularly in Lake Mangakaware, and their temporal distributions are more restricted. Subtle differences in the allocation of food resources to growth and reproduction, when food quality and quantity, temperature, and mixing of the water column are not predictable, may make $C$. pulchella a more able competitor than $C$. dubia in Lake Mangakaware. However, under conditions of low temperatures and probable food limitation, the short time to reproduction shown by $C$. dubia gives it an advantage in the winter and early spring, when the abundance of Mesocyclops leuckarti is low. 
The value of this study is its examination of a cladoceran community populated by four small species which exhibit differences in life history that, though subtle, are large enough to permit co-existence and govern seasonal distribution. In New Zealand, the geographical distribution of $C$. pulchella and $C$. dubia may be determined by the selective value of their different life history features in different environments. C. dubia certainly appears to exhibit a general distribution pattern associated with larger and more oligotrophic lakes than Lake Mangakaware. For example, C. dubia appears to be the only species of Ceriodaphnia in Lakes Taupo and Ototoa (Greenwood et al. 1991). In more oligotrophic systems of this type, the abundance of unpalatable algae is usually lower and the role of picoplankton as a food source is likely to be more important than in eutrophic systems (Burns \& Stockner 1991). Moreover, C. dubia seems to be the predominant species of Ceriodaphnia in the South Island where winter temperatures are lower (Greenwood et al. 1991). In contrast, C. pulchella's distribution appears to be largely restricted to small North Island lakes of high trophy. This suggests that the differences observed here between the life history features of these two species are not peculiar to Lake Mangakaware populations, but represent quite stable strategies which are just as distinctive as those exhibited by north temperate large and small species.

\section{ACKNOWLEDGMENTS}

We thank Joke Baas for her assistance with algal identification and enumeration, and V. Korinek for taxonomic assistance. TLG acknowledges funding assistance from the University Grants Committee, and the Hilary Jolly Fund of the University of Waikato. Lee Laboyrie provided technical assistance.

\section{REFERENCES}

Anderson, D. H.; Benke, A. C. 1994. Growth and reproduction of the cladoceran Ceriodaphnia dubia from a forested floodplain swamp. Limnology and Oceanography 39: 1517-1527.

Boersma, M.; Vijverberg, J. 1996: Food effects on life history traits and seasonal dynamics of Ceriodaphnia pulchella. Freshwater Biology 35: 25-34.

Brooks, J. L.; Dodson, S. I. 1965: Predation, body size, and the composition of plankton. Science 150: $28-35$.
Burgis, M. . 1967: A quantitative study of reproduction in some species of Ceriodaphnia (Crustacea: Cladocera). Journal of Animal Ecology 36: 6175.

Burns, C. W. 1992: Population dynamics of crustacean zooplankton in a mesotrophic lake, with emphasis on Boeckella hamata Brehm (Copepoda: Calanoida). Internationale Revue der gesamten Hydrobiologie 77: 553-577.

Burns, C. W.; Stockner, J. G. 1991: Picoplankton in six New Zealand lakes: abundance in relation to season and trophic state. Internationale Revue der gesamten Hydrobiologie 76: 523-536.

Chapman, M. A.; Boubée, J. A. T. 1977. Biological survey of the lakes of the Waipa County. Report No. 1. A general summary of the survey results. Unpublished report, Department of Biological Sciences, University of Waikato, Hamilton.

Chapman, M. A.; Green, J. D. 1987: Zooplankton ecology. In: Viner, A. B. ed. Inland waters of New Zealand. DSIR bulletin 241. Wellington, DSIR Science Information Publishing Centre. Pp. 225263.

Chapman, M. A.; Green, J. D.; Jolly, V. H. 1985: Relationships between zooplankton abundance and trophic state in seven New Zealand lakes. Hydrobiologia 123: 119-136.

Chapman, M. A.; Jolly, V. H.; Flint, E. A. 1981: Limnology of Lake Rerewhakaaitu. New Zealand Journal of Marine and Freshwater Research 15: 207-224.

Chapman, M. A.; Lewis, M. H. 1976: An introduction to the freshwater Crustacea of New Zealand. Collins, Auckland.

Culver, D. A. 1980: Seasonal variation in the sizes at birth and at first reproduction in Cladocera. In: Kerfoot, W. C. ed. Evolution and ecology of zooplankton communities. University Press of New England. Pp. 358-366.

Currie, R. I.; Foxton, P. 1967: A new quantitative plankton net. Journal of the Marine Biological Association U. K. 36: 17-32.

De Mott, W. R. 1982: Feeding selectivities and relative ingestion rates of Daphnia and Bosmina. Limnology and Oceanography 27: 518-527.

De Mott, W. R. 1983: Seasonal succession in a natural Daphnia assemblage. Ecological Monographs 53: 321-340.

De Mott, W. R; Kerfoot, W. C. 1982: Competition among cladocerans: nature of the interaction between Bosmina and Daphnia. Ecology 63: 1949-1966.

Donovan, W. F. 1970: The bionomics of Bosmina in a sand-dune lake. Unpublished MSc thesis, University of Auckland, Auckland, New Zealand. 
Duncan, A. 1989: Food limitation and body size in the life cycles of planktonic rotifers and cladocerans. Hydrobiologia 186/187: 11-28.

Ebert, D. 1991: The effect of size at birth, maturation threshold and genetic differences on the life history of Daphnia magna. Oecologia 86: 12431250

Geller, W.; Muller, H. 1981: The filtration apparatus of Cladocera: filter mesh-sizes and their implications on food selectivity. Oecologia (Berl.) 49: 316-321.

Gophen, M. 1976: Temperature dependence of food intake, ammonia excretion and respiration in Ceriodaphnia reticulata (Jurine) (Lake Kinneret, Israel). Freshwater Biology 6: 45 l-455.

Green, J. 1956: Growth, size and reproduction in Daphnia (Crustacea: Cladocera). Proceedings of the Zoological Society, London 126: 173-206.

Green, J. D. 1968: Limnological studies on a Waitakere Reservoir. Unpublished MSc thesis, University of Auckland Library, Auckland, New Zealand.

Greenwood, T. L. 1987: Comparative ecological studies on three New Zealand planktonic Cladocera. Unpublished MSc thesis, University of Waikato, Hamilton, New Zealand.

Greenwood, T. L. 1993: Life history strategies of New Zealand Ceriodaphnia (Crustacea: Cladocera): a comparative study. Unpublished DPhil thesis, University of Waikato, Hamilton, New Zealand.

Greenwood, T. L.; Green, J. D.; Chapman, M. A. 1991: New Zealand Ceriodaphnia species: identification of Ceriodaphnia dubia Richard, 1894 and Ceriodaphnia cf. pulchella Sars, 1862. New Zealand Journal of Marine and Freshwater Research 25: 283-288.

Hall, D. J.; Threlkeld, S. T.; Burns, C. W.; Crowley, P. H. 1976: The size-efficiency hypothesis and the size structure of zooplankton communities. Annual Review of Ecology and Systematics 7: 177-208.

James, M. R. 1991: Sampling and preservation methods for the quantitative enumeration of microzooplankton. New Zealand Journal of Marine and Freshwater Research 31: 305-310.

Jamieson, C. D. 1980: The predatory feeding of copepodid stages III to adult Mesocyclops leuckarti (Claus). In: Kerfoot, W. C. ed. Evolution and ecology of zooplankton communities. Hanover, University Press of New England. Pp. 518-537.

Jellyman, D. J. 1989: Diet of two species of freshwater eel (Anguilla spp.) in Lake Pounui, New Zealand. New Zealand Journal of Marine and Freshwater Research 23: 1-10.
Jeppesen, E.; Lauridsen, T.; Mitchell, S. F.; Burns, C. W. 1997: Do planktivorous fish structure the zooplankton communities in New Zealand lakes? New Zealand Journal of Marine and Freshwater Research 31: 163-173.

Kerfoot, W. C. 1974: Egg-size cycle of a cladoceran. Ecology 55: 1259-1270.

Koste, W. 1978: Rotatoria. Die Räderfiere Mitteleuropas. Bestimmungswerk Begründet von Max Voight. 2 Vols. Borntraeger, Stuttgart.

Lair, N. 1991: Grazing and assimilation rates of natural populations of planktonic cladocerans in a eutrophic lake. Hydrobiologia 215: 51-61.

Lewis, W. M. Jr. 1978: A compositional, phytogeographical and elementary structural analysis of the phytoplankton in a tropical lake: Lake Lanao, Philippines. Journal of Ecology 66: 213-226.

Lynch, M. 1978: Complex interactions between natural coexploiters-Daphnia and Ceriodaphnia. Ecology 59: 552-564.

Lynch, M. 1980a: The evolution of cladoceran life histories. The Quarterly Review of Biology 55: 23-42.

Lynch, M. 1980b: Predation, enrichment, and the evolution of cladoceran life histories: a theoretical approach. In: Evolution and ecology of zooplankton communities. University Press of New England. Pp. 367-387

Makarewicz, J. C.; Likens, G. E. 1975: Niche analysis of a zooplankton community. Science 190: 1000 1003.

Malthus, T. J.; Mitchell, S. F. 1990: On the occurrence, causes and potential consequences of low zooplankton to phytoplankton ratios in New Zealand lakes. Freshwater Biology 22: 383-394.

Perrin, N.; Bradley, M. C.; Calow, P. 1990: Plasticity of storage allocation in Daphnia. Oikos 59: 70-74.

Prepas, E. 1978: Sugar frosted Daphnia: an improved fixation technique for Cladocera. Limnology and Oceanography 23: 557-559.

Romanovsky, Y. E. 1984a: Individual growth rates as a measure of competitive advantages in cladoceran crustaceans. Internationale Revue der gesamten Hydrobiologie 69: 613-632.

Romanovsky, Y. E. 1984b: Prolongation of post-embryonic development in experimental and natural cladoceran populations. Internationale Revue der gesamten Hydrobiologie 69: 147-157.

Romanovsky, Y. E.; Feniova, I. Y. 1985: Competition among Cladocera: effect of different levels of food supply. Oikos 44: 243-252.

Ruttner-Kolisko, A. 1974: Plankton rotifers, biology and taxonomy. Die Binnengewasser Supplement 26: $1-146$. 
Smirnov, N. N.; Timms, B. V. 1983: A revision of the Australian Cladocera. Records of the Australian Museum, Supplement 1. 132 p.

Sommer, U.; Gliwicz, Z. M.; Lampert, W.; Duncan, A. 1986: The PEG-model of seasonal succession of planktonic events in freshwaters. Archiv für Hydrobiologie 106: 433-471.

Staples, J. A. 1984: Life history and population dynamics of Ceriodaphnia dubia Richard in Lake Grasmere, Canterbury. Unpublished MSc thesis, University of Canterbury, Christchurch, New Zealand.

Stearns, S. 1976: Life history tactics: a review of the ideas. The Quarterly Review of Biology 5l: 3-47.

Tessier, A. J. 1986: Comparative population regulation of two planktonic Cladocera (Holopedium gibberum and Daphnia catawba). Ecology 67: 285-302.

Tessier, A. J.; Goulden, C. E. 1982: Estimating food limitation in cladoceran populations. Limnology and Oceanography 27: 707-717.

Tessier, A. J.; Goulden, C. E. 1987: Cladoceran juvenile growth. Limnology and Oceanography 32: 680 686.

Threlkeld, S. T. 1979: Estimating cladoceran birth rates: the importance of egg mortality and the egg age distribution. Limnology and Oceanography 24: 601-612.
Urabe, J. 1991: Effect of food concentration on the carbon balance of Bosmina longirostris (Crustacea: Cladocera). Freshwater Biology 26: 57-68.

Utermöhl, H. 1958: Zur vervollkommnung der quantitativen phytoplankton-methodik. Mitteilungen Internationale Vereinigung für theoretische und angewandte Limnologie 9: 138.

Vanni, M. J. 1987: Effects of food availability and fish predation on a zooplankton community. Ecological Monographs 57: 61-88.

Vijverberg, J. 1980: Effect of temperature in laboratory studies on development and growth of Cladocera and Copepoda from Tjeukemeer, The Netherlands. Freshwater Biology 10: 317-340.

White, E. 1983: Lake eutrophication in New Zealand-a comparison with other countries of the Organisation for Economic Co-operation and Development. New Zealand Journal of Marine and Freshwater Research 17: 437-444.

Wilkinson, L. 1997: SYSTAT ${ }^{(1)} 7.0$ statistics. Chicago, SPSS Inc.

Zar, J. H. 1996: Biostatistical analysis. 3rd edition. London, Prentice-Hall International. 